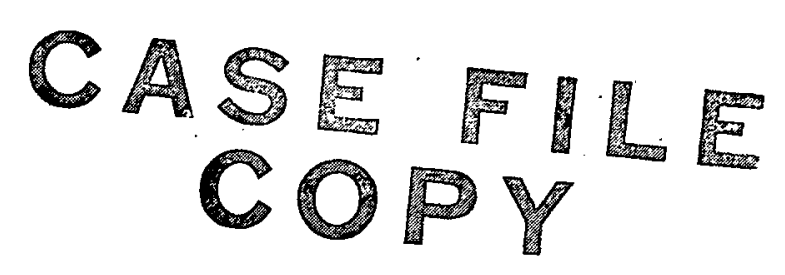

\title{
A LIFE STUDY OF AISI M-50 AND SUPER NITRALLOY SPUR GEARS WITH AND WITHOUT TIP RELIEF
}

by Dennis P. Townsend and Erwin V. Zaretsky

Lewis Research Center

Cleveland, Ohio 44135.

TECHNICAL PAPER proposed for presentation at Joint Lubrication Conference cosponsored by the American Society of Lubrication Engineers and American Society of Mechanical Engineers Atlanta, Georgia, October 16-18, 1973 
A LIFE STUDY OF AISI M-50 AND SUPER NITRALLOY SPUR GEARS WITH AND WITHOUT TIP RELIEF

by Dennis P. Townsend* and Erwin V. Zaretsky*

Lewis Research Center

National Aeronautics and Space Administration

Cleveland, Ohio 44135

\section{ABSTRACT}

Tests were:conducted at $350 \mathrm{~K}\left(170^{\circ} \mathrm{F}\right)$ with groups of $8.9 \mathrm{~cm}$ (3.5-in.)-pitch-diameter spur gear with and without tip relief made of consumable-electrode vacuum melted (CVM) Super Nitralloy (5Ni-2Al) and CVM AISI M-50 steel. The AISI M-50 gears without tip relief had lives approximately 50 percent longer than the Super Nitralloy gears without tip relief. However, the Super Nitralloy gears with tip relief had lives equal to the AISI M-50 gears without tip relief. The difference in lives were not statistically significant. All gears failed by classical pitting fatigue at the pitch circle. However, the AISI M-50 gears with tip relief failed by tooth fracture. AISI M-50 gear sets without tip relief having a spalled gear tooth which were deliberately overrun after spalling had occurred, failed by tooth fracture.

\section{INTRODUCTION}

There is an increasing need in high performance aircraft for increased power density and power to weight ratio. This is especially true in vertical takeoff and landing (VTOL), short takeoff and landing (STOL), and geared

*Members, ASME. 
fan type aircraft. In addition, increased engine Mach number and higher engine performance characteristics are causing increased temperature demands on aircraft gear materials.

One of the limitations of gear technology which prevents meeting more stringent aircraft requirements is a lack of knowledge relating to certain gear materials. This lack of knowledge relates to a material notch sensitivity and surface load-carrying capacity. Gear teeth will generally fail because of tooth breakage and surface distress in addition to surface pitting (rolling-element fatigue). Increased gear-tooth loading will, of course, aggravate these problems.

Tooth bending endurance testing has been performed on gears over a period of several decades. However, the results of such tests have not been definitive [1] $]^{1}$. Results obtained in rolling-element fatigue tests [2] show that the following parameters can significantly affect fatigue life: material hardness, material heat treatment, lubricant type and batch, temperature, surface finish, operating speed, and contact stress. Unfortunately, these variables have not been carefully controlled (or have not been controlled at all) in gear testing. In some instances, insufficient tests were statistically inconclusive. Furthermore, some tooth bending fatigue tests which have been performed [3] have resulted in fretting fatigue rather than bending fatigue, wherein tooth fracture occurred at an incipient spall caused by fretting.

An advanced material which has been used in aircraft gear applications

${ }^{1}$ Numbers in brackets designate references at end of paper. 
is Super Nitralloy (5Ni-2Al). This material, which has shown good gear load-carrying capacity [1], is similar to Nitralloy N. The Super Nitralloy (5 Ni-2Al) has additional alloying element comprising 2-percent nickel and 1-percent aluminum to give it better hot hardness characteristics and a better nitriding capability. The Nitralloy $\mathrm{N}$ material has been used for aircraft gears and splines for many years and was used for high temperature lubricant testing in [4,5]. Bending fatigue tests [1] of Super Nitralloy (5Ni-2Al) gear teeth indicate that this material has very good strength properties at temperatures to $644 \mathrm{~K}\left(700^{\circ} \mathrm{F}\right)$.

Another material which has wide acceptance in aircraft applications for moderate to high temperatures is AISI M-50 steel [6]. This material has been used mainly as a bearing steel. However, there has been limited application of this material for gears in aircraft accessory gear boxes. This material has an operating temperature potential in excess of $589 \mathrm{~K}$ $\left(600^{\circ} \mathrm{F}\right)[7]$.

The objective of the research described in this paper was to compare under closely controlled test conditions the fatigue lives and failure modes of test spur gears made of Super Nitralloy ( $5 \mathrm{Ni}-2 \mathrm{Al}$ ) and of AISI M-50 steel. The results reported herein are based on data which were initially reported in $[8,9]$.

\section{TEST GEARS AND MATERIALS}

The test gears used in the tests reported herein are shown in Fig. 1. Dimensions for the test gears are summarized in table 1. All gears had nominal surface finish on the tooth face of $0.406 \mu \mathrm{m} \mathrm{rms} \mathrm{(16 \mu in.} \mathrm{rms}$ ) and a standard $20^{\circ}$ involute tooth profile with and without tip relief. 
The test gears were manufactured from two materials. These were consumable-electrode vacuum melted (CVM) Super Nitralloy (5Ni-2Al) and CVM AISI M-50 steel. The chemical compositions of these materials are given in table 2.

The gears manufactured from the CVM AISI M-50 material were throughhardened to a Rockwell $\mathrm{C}$ hardness of $62 \pm 1$. The gears were finished ground after heat treatment.

The gears manufactured from the CVM Super Nitralloy (5Ni-2Al) material were nitrided to a Rockwell $C$ hardness of $61.5 \pm 1$, at a case depth of 0.046 to $0.061 \mathrm{~cm}(0.018$ to $0.024 \mathrm{in}$.), with a maximum white layer of $0.0013 \mathrm{~cm}(0.0005$ in.). (The white layer is iron nitride which for ms during the nitriding process. By proper control of the nitriding conditions, the depth of the white layer can be kept to a minimum.) The core hardness was Rockwell C $44 \pm 1$. The gears without tip relief were ground before nitriding and had a mat finish due to the nitriding process. The tip relief gears were finish ground after nitriding with a tip relief as shown in Fig. 2.

The short-term hot hardness data (from [7, 10]) for the AISI M-50 and the Super Nitralloy materials are shown in Fig. 3. This figure shows that the AISI M-50 material has a slightly better short-term hot hardness characteristic than the Super Nitralloy material. Microhardness measurements of the Super Nitralloy gears showed that the gears with tip relief were approximately Rockwell $\mathrm{C} 60$ as compared to a Rockwell $\mathrm{C}$ hardness of approximately 61 for the gears without tip relief.

\section{GEAR TEST APPARATUS}

The gear fatigue tests were performed in the gear test apparatus, shown 
in Fig. 4 and initially described in [8]. This test rig uses the four-square principle of applying the test gear load so that the input drive need only overcome the frictional losses in the system.

A schematic of the test rig is shown in Fig. 4(b). Oil pressure and leakage flow is supplied to the load vanes through a shaft seal. As the oil pressure is increased on the load vanes inside the slave gear, torque is applied to the shaft. This torque is transmitted through the test gears back to the slave gear, where an equal but opposite torque is maintained on the slave gear by the oil pressure. This torque on the test gears, which depends on the hydraulic pressure applied to the load vanes, loads the gear teeth to the desired stress level. The two identical test gears can be started under no load. The load can be applied gradually without changing the running track on the gear teeth.

Separate lubrication systems are provided for the test gears and the main gearbox. The two lubricant systems are separated at the gearbox shafts by pressurized labyrinth seals. Nitrogen was used as the seal gas. The test gear lubricant is filtered through a 5- $\mu \mathrm{m}$ fiber-glass filter.

A vibration transducer is mounted on the gearbox adjacent to the test gears. The transducer is used to automatically shut off the test rig when a surface-fatigue (pitting) failure occurs on a gear tooth. The gearbox is also automatically shut off if there is a loss of oil flow to either the main gearbox or to the test gears, if the test gear oil overheats or if there is a loss of seal gas pressurization.

\section{TEST LUBRICANT}

All tests were conducted with a single batch of super-refined naphthenic 
mineral-oil lubricant having proprietary additives (antiwear, antioxidant, and antifoam). The physical properties of this lubricant are summarized in table 3. Five percent of an extreme pressure additive, designated Anglamol 81, with a chemical analysis as given in table 4 was added to the lubricant. Lubricant flow rate was held constant at $800 \mathrm{cu} \mathrm{cm} / \mathrm{min}$ $(0.21 \mathrm{gal} / \mathrm{min})$. The lubricant was supplied to the inlet mesh of the gear set by an oil jet. Lubricant inlet temperature was constant at $319 \pm 6 \mathrm{~K}$ $\left(115^{\circ} \pm 10^{\circ} \mathrm{F}\right)$. Lubricant outlet temperature, which was measured at the outlet of the test-gear cover, was nearly constant at $350 \pm 3 \mathrm{~K}\left(170^{\circ}{ }_{ \pm}^{\circ} \mathrm{F}\right)$. A nitrogen cover gas was used throughout a test in order to assure that the oil would not oxidize. However, the cover gas by excluding oxygen, affected the chemical reactivity of the additive with the metal surface. Thus the effectiveness of the additives in boundary lubrication of the gear teeth was reduced.

\section{TEST PROCEDURE}

The test gears were cleaned to remove the preservative and were assembled on the test rig. The test gears were run in an offset condition, with a $0.28 \mathrm{~cm}$ (0.110 in.) tooth-surface overlap to give a load surface on the gear face of $0.25 \mathrm{~cm}(0.100 \mathrm{in})$ of the $0.635-\mathrm{cm}(0.250$-in )-wide gear, thereby allowing for edge radius of the gear teeth By testing both faces of the gears, a total of four fatigue tests could be run for each set of gears All tests were run-in at a load of $2713 \mathrm{~N} / \mathrm{cm}(1550 \mathrm{lb} / \mathrm{in}$.) of face for $1 \mathrm{hr}$.

The load was then increased to $7525 \mathrm{~N} / \mathrm{cm}\left(4300 \mathrm{lb} / \mathrm{in}\right.$.) and $190 \times 10^{7} \mathrm{~N} / \mathrm{m}^{2}$ (275 000 psi) pitch-line Hertz stress。 
The test gears were operated at $10000 \mathrm{rpm}$, which gave a pitch-line velocity of $4655 \mathrm{~m} / \mathrm{sec}(9163 \mathrm{ft} / \mathrm{min})$. Lubricant was supplied to the inlet mesh at $800 \mathrm{cu} \mathrm{cm} / \mathrm{min}$ at $319 \pm 6 \mathrm{~K}\left(115 \pm 10^{\circ} \mathrm{F}\right)$. The tests were continued 24 hours a day until failure. A total of $3785 \mathrm{cu} \mathrm{cm}$ of (one gal) lubricant was used for each test and was discarded, along with the filter element, after each test.

The pitch-line elastohydrodynamic (EHD) film thickness was calculated by the method of [11]. It was assumed, for this film thickness calculation, that the gear blank temperature at the pitch line was equal to the outlet oil temperature and that the inlet oil temperature to the contact zone was equal to the gear temperature, even though the oil inlet temperature was considerably lower. It is probable that the gear surface temperature could be even higher than the oil outlet temperature, especially at the end points of sliding contact. The EHD film thickness for the above conditions was computed to be $0.65 \mu \mathrm{m}$ (26 $\mu$ in.), which gave a ratio of film thickness to composite surface roughness $(\mathrm{h} / \sigma)$ of 1.13 .

\section{RESULTS AND DISCUSSION}

\section{Fatigue Results}

Two groups of test gears made from CVM AISI M-50 steel and CVM Super Nitralloy (5Ni-2Al) were run in pairs until a failure occurred. Each test was terminated when a fatigue spall occurred on one of the two gears. Test results were analyzed statistically by considering each pair of gears as a system.

Pitting fatigue results for the gear system made from the AISI M-50 material are shown in Fig. 5(a). The failure index indicates the number of 
fatigue failures out of the number of gear pairs tested. These data were analyzed by the methods of [12] and are summarized in table 5 .

A typical fatigue spall for the AISI M-50 gears is shown in Fig. 6 . Metallurgical examination of all failures indicated that the fatigue spalls were of subsurface origin and were initiated at the pitch circle. The subsurface-initiated spall is characterized by a plurality of subsurface cracks emanating below the surface and propagating into a crack network. Eventually these develop into a typical fatigue spall or pit. An unfailed gear tooth run to 91 and 73 hours, respectively, on the two tracks is shown in Fig. 7. The fatigue lives of the gear sets made from Super Nitralloy are shown in Fig. 5(b). These data are summarized in table 5. As with the AISI M-50 material, the fatigue spalls were of subsurface origin. The unfailed Super Nitralloy gear teeth are identical in appearance to the AISI M-50 gear teeth. These data indicate that the M-50 gears have a life 50 percent greater than the Super Nitralloy gears at a 90 -percent probability of survival.

The confidence that can be placed in the experimental results was determined statistically with the use of the methods given in [12]. The Super Nitralloy gears we compared with the M-50 gears. Confidence numbers for the 90-percent probability of survival, or 10-percent life, were calculated and are presented in table 5. The confidence of 70 percent of M-50 relative to Super Nitralloy means that 70 out of 100 times the 10 percent life of the Super Nitralloy gears will be less than that of the M-50 gears. A 68-percent confidence is approximately equal to a one-sigma deviation, which, for statistical purposes, is considered to be insufficient 
to conclude that there is any difference in the 10-percent life between materials. Hence, from these data, the fatigue-life difference between the M-50 and the Super Nitralloy steels can be considered to be statistically insignificant at nominal temperatures.

Several spalled gears of both materials were deliverately run for several hours in this condition. For the M-50 gears, the spalled tooth would fracture, generally within a $2-\mathrm{hr}$ period or within $1.2 \times 10^{6}$ revolutions. This was not totally unexpected inasmuch as the M-50 material is very notch sensitive. The crack size necessary for catastrophic crack growth is very small. Thus, when a fatigue spall (notch) forms, the tooth becomes susceptible to fatigue fracture.

The Super Nitralloy, while having a hard surface, has a soft, ductile core. Since the rate of crack growth is much lower in the ductile core, the material is notch insensitive. Thus, when a fatigue spall (notch) forms, the tooth is not very susceptible to fatigue fracture. This was verified in the tests reported herein, where none of the spalled teeth that were deliberately overrun failed because of fracture.

These results verify the need for a soft core in critical applications where the probability of failure is high. However, the M-50 material, with a Rockwell $\mathrm{C}$ hardness of 62 , had a longer life (although statistically insignificant) than the Super Nitralloy material, which has a case Rockwell C hardness of 61.5 . Based on the hardness characteristics of the two materials, the M-50 material may have greater high-temperature pitting fatigue life potential because of its higher hot hardness. The Super Nitralloy material is probably usable to $589 \mathrm{~K}\left(600^{\circ} \mathrm{F}\right)$ if oxidation stability is dis- 
counted. This would imply that the fabrication of gears from an M-50 type material with a soft core may be beneficial to long gear life.

Tip Relief

Two additional groups of test gears made from CVM AISI M-50 steel and CVM Super Nitralloy (5Ni-2Al) having tip relief were run under identical conditions as those gears without tip relief。 These gears were made from the same: respective heats of material as those gears without tip relief. The effect of tip relief on gear tooth loading is illustrated in Fig. 8. While the maximum load or stress is the same for both the standard and modified (tip relief) gear profile, the stressed volume under the high stress and the resultant moment loading on the gear teeth are increased.

Test results with the Super Nitralloy (5Ni-2Al) gears with tip relief are shown in Fig, 9 and are compared with the results obtained without tip relief。 Test results show that the gears with tip relief had a life 50 percent longer than those gears without tip relief at a 90 -percent probability of failure. However, the difference in life was not found to be statistically significant. These results are summarized in table 5.

It has been reported in [13] that tip relief may improve resistance to scoring, For the conventional gears tested no scoring failures occurred. However, several scoring failures occurred with the Super Nitralloy gears with tip relief. A typical scoring failure is shown in Fig. 10. From these results, it may be concluded that, at least under some heavily loaded conditions, tip relief may increase the incidence of scoring.

The purpose of the tip relief is to reduce the loading at the end point of tooth contact at the addendum where high sliding takes place. This also 
causes better engagement of the contacting teeth. However, the reduced loading at the end point must be accounted for at another location in the tooth contact. This location is above the pitch point in the addendum region. The combination of the increased loading and sliding at this location probably accounts for the increased tooth scoring. (The scoring can be explained on the basis of a decreased elastohydrodynamic film due to increased heat gener ation and loading.)

Gears made from CVM AISI M-50 presented a particularly difficult problem. Those conventional M-50 gears which were deliverately overrun for a period of two hours after a fatigue spall had occurred exhibited tooth fracture due to conventional bending fatigue. The spall was analogous to a notch and thus acted as a stress raiser.

For the AISI M-50 gears with tip relief 9 out of 10 gear: sets tested failed by tooth fracture. The fracture fatigue life at a 90 -percent probability of survival was approximately 685000 revolutions $(1.14 \mathrm{hr})$ [9]. This is compared to a pitting fatigue life of 27.8 million revolutions ( $46.4 \mathrm{hr}$ ) for the AISI M-50 gears without tip relief (table 5). Six of the tooth fractures with the AISI M-50 gears with tip relief originated in the root region. This is shown in Fig. 11(a). Three tooth fractures occurred at the addendum region (fig. 11(b)). It is speculated that the cause of the tooth fracture with the tip relieved AISI M-50 was nearly the same as that for the scoring with the Super-Nitralloy gears with tip relief. The maximum single tooth load condition was shifted further into the addendum region causing higher tooth bending stresses. The AISI M-50 material being through hardened and thus having a less ductile core than the case carburized Super-Nitralloy was 
susceptible to bending fatigue fracture under these conditions.

One of the AISI M-50 gears tested with tip relief failed due to surface pitting. It thus can be concluded that tip relief can cause a greater propensity in through-hardened materials to fatigue fracture.

\section{Wear}

In order to study the wear of gears, surface traces in the axial direction across the face of the gear teeth were made at the addendum, the pitch line, and dedendum for the gears without tip relief. Typical results from these data are summarized in table 6. They were approximately $12.7 \mu \mathrm{m}(500 \mu \mathrm{in}$.$) average wear across the tooth face for the M-50 gears.$ It is thought that this amount of wear is due to "run in" and is not progressive in nature. The wear at the pitch line, where rolling occurs, was somewhat less, as would be expected. However, no systematic measurements of wear with time were made which would verify this speculation.

Wear measurements for the Super Nitralloy gear teeth indicated that the average wear was approximately $7.6 \mu \mathrm{m}(300 \mu \mathrm{in}$.$) . This amount was$ less than with the M-50 material. As with the M-50 gears there was no general relation between running time and wear. The measured wear was apparently due to ${ }^{81} \mathrm{run}$ in, ${ }^{89}$ as with the M-50 material.

\section{SUMMARY}

Tests were conducted with groups of $8.9 \mathrm{~cm}(3.5$-in.)-pitch-diameter spur gears with and without tip relief made of consumable-electrode vacuum meited (CVM) Super Nitralloy (5Ni-2Al) and CVM AISI M-50 steel, at a temperature of $350 \mathrm{~K}\left(170^{\circ} \mathrm{F}\right)$, a maximum contact (Hertz) stress of $190 \times 10^{7} \mathrm{~N} / \mathrm{m}^{2}$ (275 $\left.000 \mathrm{psi}\right)$, and at a speed of $10000 \mathrm{rpm}$. 
1. The AISI M-50 gears without tip relief had lives approximately 50 percent longer than the Super Nitralloy gears without tip relief at a 90 -percent probability of survival. However, the difference in life was not statistically significant.

2. The Super Nitralloy gears with tip relief had lives approximately 50 percent longer than the Super Nitralloy without tip relief or a life approximately equal to the AISI M-50 gears without tip relief. The difference in life was not statistically significant.

3. Both the AISI M-50 without tip relief and the Super Nitralloy gears with and without tip relief failed from classical pitting fatigue at the pitch circle. That is, the gear teeth failed because of spalling which originated from subsurface cracks. The spall was limited in area and depth of penetration. The AISI M-50 gears with tip relief failed by tooth fracture.

4. The AISI M-50 gear sets without tip relief having a spalled gear tooth which were deliberately overrun, failed within $2 \mathrm{hr}$ after spalling had occurred because of tooth fracture fatigue. Under the same conditions, the Super Nitralloy material did not fail.

REFERENCES

1. Seabrook, J. B., and Dudley, D. W., "'Results of a Fifteen-Year

Program of Flexural Fatigue Testing of Gear Teeth, " J. Eng. Ind., Vol. 86, No. 3, Aug. 1964, pp. 221-239.

2. Zaretsky, E. V., and Anderson, W. J., "'Effect of Materials: General Background, ${ }^{\circ}$ Interdisciplinary Approach to the Lubrication of Concentrated Contacts, P. M. Ku, ed., NASA SP-237, 1970, pp. 379-408. 
3. Ierranski, A. J., and Rose, H. J., "Evaluation of Advanced Gear Materials for Gear Boxes and Transmissions, "Rep. D210-10345-1, Boeing Co., Sept. 1971.

4. Beane, G. A., IV, and Lawler, C W., "Load-Carrying Capacities of Gear Lubricants of Different Chemical Classes Based on Results Obtained with WADD High-Temperature Gear Machine Used with Induction-Heated Test Gears, "Southwest Research Inst. (AFAPLTR-65-23, AD-620294), Apr. 1965.

5. Jackson, E. G., Muench, C. F., and Scott, E. H.: Evaluation of Gear Materials Scoring at $700^{\circ}$ F. ASLE Trans., Vol. 3, No. 1, 1960, pp. 69-82.

6. Bamberger, E. N., Zaretsky, E. V., and Anderson, W. J., "Fatigue Life of $120-\mathrm{mm}$ Bore Ball Bearings at $600^{\circ} \mathrm{F}$ with Fluorocarbon, Polyphenyl Ether, and Synthetic Paraffinic Base Lubricants, " NASA TN D-4850, 1968.

7. Chevalier, J. L., Dietrich, M. W., and Zaretsky, E. V., "ShortTerm Hot Hardness Characteristics of Rolling-Element Steels, " NASA TN D-6632, 1972.

8. Townsend, D. P., Chevalier, J. L., and Zaretsky, E. V., "Pitting Fatigue Characteristics of AISI M-50 and Super Nitralloy Spur Gears," NASA TN D-7261, 1973.

9. Townsend, D. P., and Zaretsky, E. V., "Effect of Tip Relief on Endurance Characteristics of Super-Nitralloy (5Ni-2Al) and AISI M-50 Spur Gears, "Proposed NASA Technical Note, 1973.

10. Chevalier, J. L., Dietrich, M. W., and Zaretsky, E. V., "Hot Hardness Characteristics of Ausformed AISI M-50, Matrix II, WD-65, Modified AISI 400-C, and Super Nitralloy, " NASA TN D-7091, 1973. 
11. Dowson, D., and Higginson, G. R., "Elasto-Hydrodynamic Lubrication, "Pergamon Press, 1966.

12. Johnson, L. G., "The Statistical Treatment of Fatigue Experiments," Elserris Publishing Co., 1964.

13. Borsoff, V. N., "On the Mechanism of Gear Lubrication," J. Basic Eng., Vol. 81, No. 1, 1959, pp. 79-93. 
TABLE I. - GEAR DATA

[Gear tolerance per AGMA class 12.]

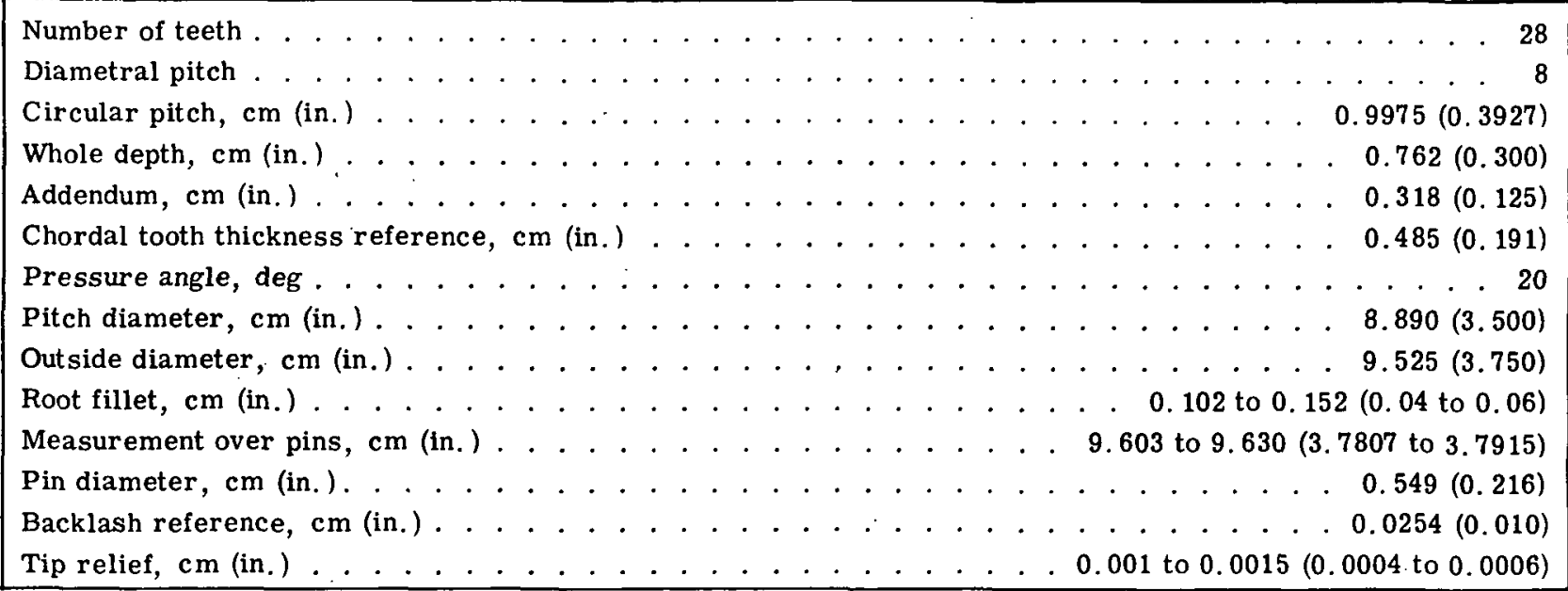

TABLE II. - CHEMICAL COMPOSITION OF

GEAR MATERIALS BY PERCENT WEIGHT

\begin{tabular}{|l|c|c|}
\hline \multirow{2}{*}{ Element } & \multicolumn{2}{|c|}{ Gear material } \\
\cline { 2 - 3 } & AISI M -50 steel & $\begin{array}{c}\text { Super Nitralloy } \\
\text { (5Ni-2Al) }\end{array}$ \\
\hline Carbon & 0.85 & 0.24 \\
Manganese & .28 & .25 \\
Phosphorous & .010 & .005 \\
Sulfur & .004 & .003 \\
Silicon & .23 & .22 \\
Copper & .06 & $-\ldots--$ \\
Chromium & 4.17 & .58 \\
Molybdenum & 4.23 & .26 \\
Vanadium & .97 & .12 \\
Nickel & .08 & 5.16 \\
Cobalt & .03 &..-- \\
Tungsten & .08 & $-\ldots .--$ \\
Aluminum & $\ldots-.-$ & 2.06 \\
Iron & Balance & Balance \\
\hline
\end{tabular}


TABLE III. - PROPERTIES OF SUPER-REFINED, NAPHTHENIC, MINERAL-OIL TEST LUBRICANT

Kinematic viscosity, $\mathrm{cm}^{2} / \mathrm{sec}(\mathrm{cS})$, at

$266 \mathrm{~K}\left(20^{\circ} \mathrm{F}\right)$. . . . . . . . . . . . . . . . . . . . . . . . . . . . . . . . . . $2812 \times 10^{-2}(2812)$

$311 \mathrm{~K}\left(100^{\circ} \mathrm{F}\right)$. . . . . . . . . . . . . . . . . . . . . . . . . . . . . . . . . . $73 \times 10^{-2}(73)$

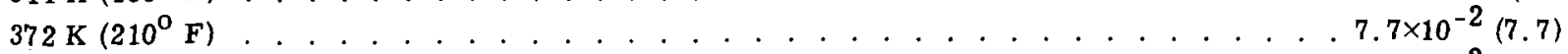

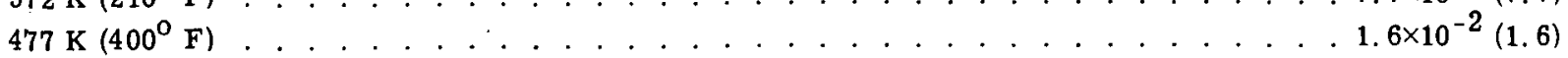

Flash point, $\mathrm{K}\left({ }^{\mathrm{O}} \mathrm{F}\right)$. . . . . . . . . . . . . . . . . . . . . . . . . . . . . . . . . . . . 489(420)

Autoignition temperature, $\mathrm{K}\left(\mathrm{CF}_{\mathrm{F}}\right.$. . . . . . . . . . . . . . . . . . . . . . . . . . . . . 664 (735)

Pour point, $\mathrm{K}\left({ }^{\mathrm{O}} \mathrm{F}\right)$. . . . . . . . . . . . . . . . . . . . . . . . . . . . . . . . . . . 236 (-35)

Density at $289 \mathrm{~K}\left(60^{\circ} \mathrm{F}\right), \mathrm{g} / \mathrm{cm}^{3}$. . . . . . . . . . . . . . . . . . . . . . . . . . . . . . . . . 0.8899

Vapor pressure at $311 \mathrm{~K}\left(100^{\circ} \mathrm{F}\right), \mathrm{mm} \mathrm{Hg}$ (or torr) . . . . . . . . . . . . . . . . . . . . . . . . 0.01

Ther mal conductivity at $311 \mathrm{~K}\left(100^{\circ} \mathrm{F}\right), \mathrm{J} /(\mathrm{m})(\mathrm{sec})(\mathrm{K})\left(\mathrm{Btu} /(\mathrm{hr})(\mathrm{ft})\left({ }^{\circ} \mathrm{F}\right)\right)$. . . . . . . . . . . $0.04(0.07 .25)$

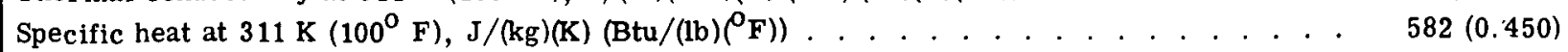

TABLE IV. - PROPERTIES OF LUBRICANT ADDITIVE ANGLAMOL 81

Percent phosphorous by weight . . . . . . . . . . . . . . . . . . . . . . . . . . . . . 0.66

Percent sulfur by weight. . . . . . . . . . . . . . . . . . . . . . . . . . . . . . . . 13.41

Specific gravity. . . . . . . . . . . . . . . . . . . . . . . . . . . . . . . . . . . . 0.982

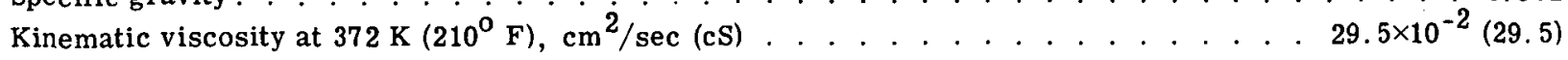

TABLE V. - FATIGUE LIFE RESULTS FOR CVM AISI M-50 STEEL

AND CVM SUPER NITRALLOY (5Ni-2Al) SPUR GEARS

Maximum Hertz stress at pitch line $190 \times 10^{7} \mathrm{~N} / \mathrm{m}^{2}(275000 \mathrm{psi})$; speed, $10000 \mathrm{rpm}$; temperature, $350 \mathrm{~K}\left(170^{\circ} \mathrm{F}\right)$; lubricant, super-refined naphthenic mineral oil.

\begin{tabular}{|c|c|c|c|c|c|c|c|}
\hline \multirow[t]{3}{*}{ Material } & \multirow{3}{*}{$\begin{array}{l}\text { Failure } \\
\text { index } \\
\text { (a) }\end{array}$} & \multicolumn{4}{|c|}{ Pitting fatigue life } & \multirow{3}{*}{$\begin{array}{l}\text { Weibull } \\
\text { slope }\end{array}$} & \multirow{3}{*}{$\begin{array}{c}\text { Confidence number } \\
(10-\text { Percent life } \\
\text { relative to Super } \\
\text { Nitralloy without } \\
\text { tip relief, percent) }\end{array}$} \\
\hline & & \multicolumn{2}{|c|}{ Hours } & \multicolumn{2}{|c|}{$\begin{array}{l}\text { Millions of } \\
\text { revolutions }\end{array}$} & & \\
\hline & & $\begin{array}{c}10-\text { Percent } \\
\text { life }\end{array}$ & $\begin{array}{l}\text { 50-Percent } \\
\text { life }\end{array}$ & $\begin{array}{c}\text { 10-Percent } \\
\text { life }\end{array}$ & $\begin{array}{c}\text { 50-Percent } \\
\text { life }\end{array}$ & & \\
\hline $\begin{array}{l}\mathrm{M}-50 \\
\text { (without tip relief) }\end{array}$ & 9 of 9 & 46.4 & 85.8 & 27.8 & 50.8 & 3.1 & 70 \\
\hline $\begin{array}{l}\text { Super Nitralloy } \\
\text { (without tip relief) }\end{array}$ & 9 of 9 & 31.6 & 73.8 & 18.9 & 44.2 & 2.2 & -- \\
\hline $\begin{array}{l}\text { Super Nitralloy } \\
\text { (with tip relief) }\end{array}$ & 10 of 10 & 49.4 & 74.06 & 29.6 & 44.3 & 4.6 & 70 \\
\hline
\end{tabular}

(a) Number of failures out of number of gear systems tested.

(b) Number of times out of 100 that additional tests will be ranked as shown relative to results with Super Nitralloy gears without tip relief. 
TABLE VI. - WEAR OF AISI CVM M-50 STEEL AND CVM

SUPER NITRALLOY (5Ni-2Al) GEAR MATERIAL

[Maximum Hertz stress at pitch line, $190 \times 10^{7} \mathrm{~N} / \mathrm{m}^{2}(275000 \mathrm{psi})$; speed, $10000 \mathrm{rpm}$; temperature, $350 \mathrm{~K}\left(170^{\circ} \mathrm{F}\right)$; lubricant, super-refined naphthenic mineral oil.]

\begin{tabular}{|c|c|c|c|c|}
\hline \multirow[t]{2}{*}{ Gear material } & \multirow{2}{*}{$\begin{array}{c}\text { Running time, } \\
\text { hr } \\
\text { (a) }\end{array}$} & \multicolumn{3}{|c|}{ Wear depth, $\mu \mathrm{m}(\mu$ in. $)$} \\
\hline & & Addendum & Pitch & Dedendum \\
\hline \multirow[t]{3}{*}{ CVM AISI M-50 steel } & 48 & $11.0(433)$ & $12.4(487)$ & $13.9(547)$ \\
\hline & 66 & $12.2(480)$ & $6.4(253)$ & $24.1(947)$ \\
\hline & 76 & $14.4(567)$ & $6.1(240)$ & $8.5(333)$ \\
\hline \multirow{4}{*}{$\begin{array}{l}\text { CVM Super Nitralloy } \\
\qquad(5 \mathrm{Ni}-2 \mathrm{Al})\end{array}$} & 42 & $12.5(493)$ & $5.8(227)$ & $9.7(380)$ \\
\hline & 76 & $1.9(73)$ & $2.0(80)$ & $3.6(140)$ \\
\hline & 118 & $6.1(240)$ & $4.2(167)$ & $16.9(667)$ \\
\hline & 140 & $5.4(213)$ & $4.1(160)$ & $7.6(300)$ \\
\hline
\end{tabular}

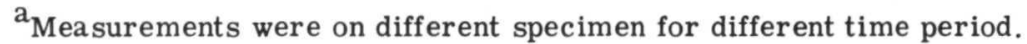

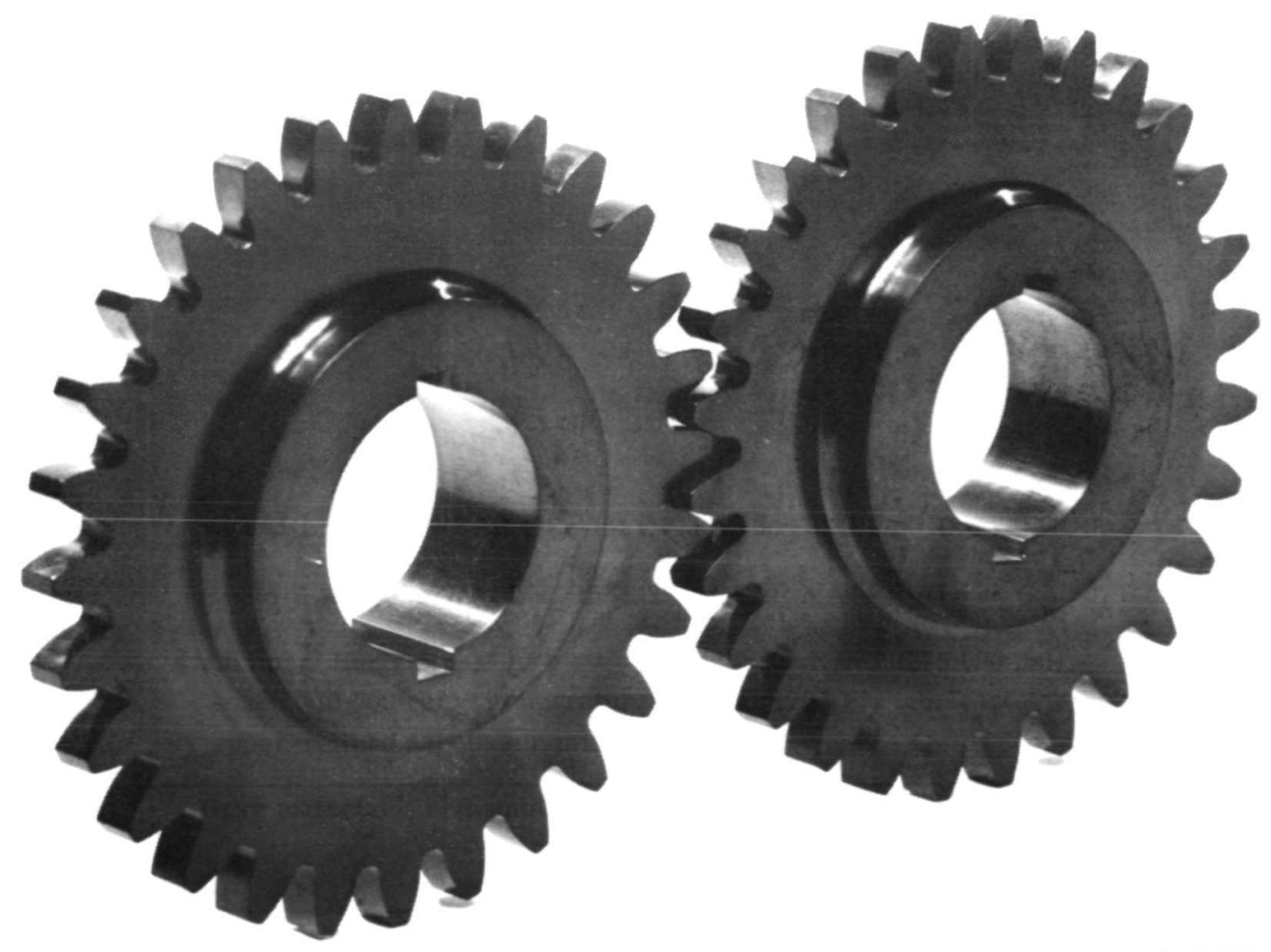

Figure 1. - Test gears. 


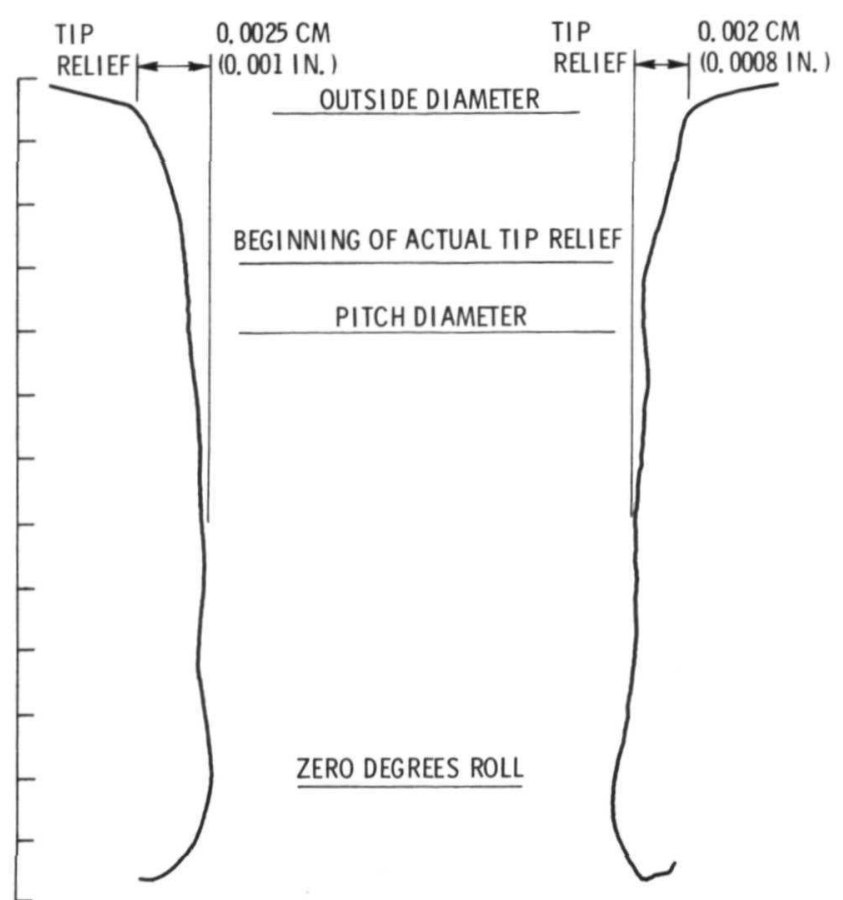

(a) SUPER NITRALLOY (5Ni-2AI).

(b) AISI M-50.

Figure 2 - Trace of involute profile deviations for super nitralloy and M-50 spun gear teeth with tip relief. (Straight line indicates a perfect involute profile. Approximately $0.003 \mathrm{~cm}(0.0002 \mathrm{in}$.) of the relief is a deviation in pressure angle.)

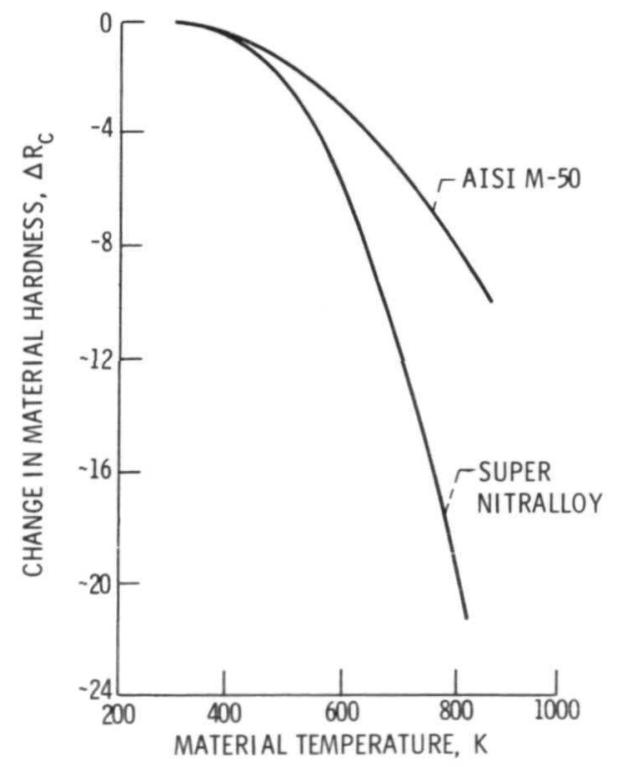

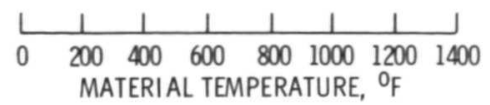

Figure 3. - Normalized short term hot hardness of AISI M-50 and super nitralloy as a function of temperature [10].

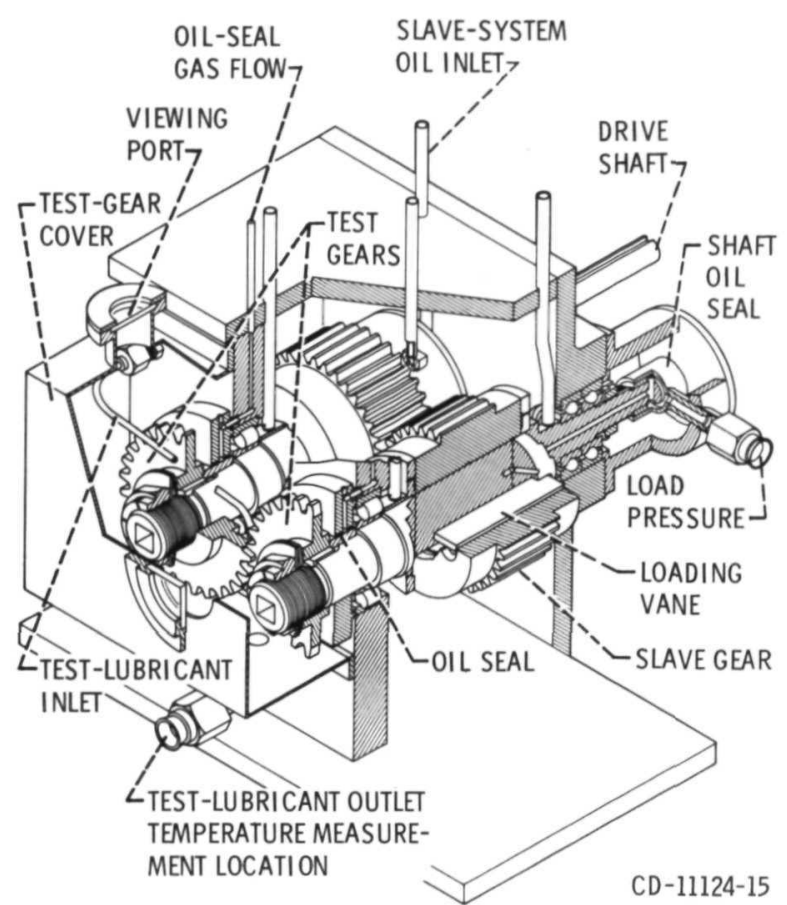

(a) CUTAWAY VIEW.

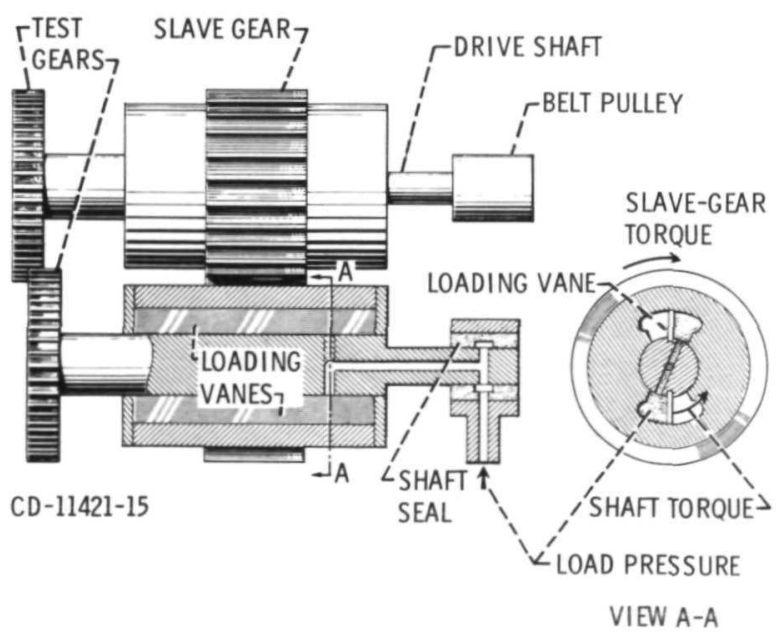

(b) SCHEMATIC DIAGRAM.

Figure 4 - Gear fatigue test apparatus. 


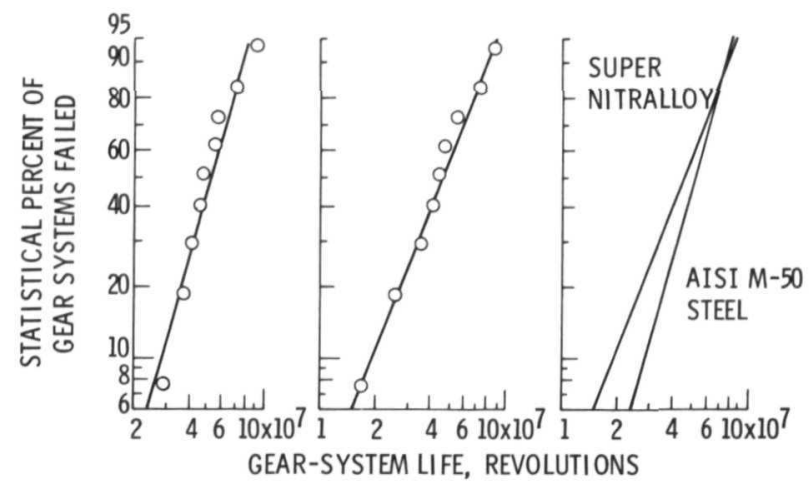

$\begin{array}{llll}\text { (a) AISI M-50 } & \text { (b) SUPER NITRALLOY } & \text { (c) COMPARISON }\end{array}$ STEEL $\quad$ (5Ni-2AI). OF RESULTS.

Figure 5. - Pitting fatigue lives of spur-gear systems made of CVM AISI M-50 steel and of CVM Super Nitralloy $(5 \mathrm{Ni}-$ 2Al) without tip relief. Maximum Hertz stress at pitch line, $190 \times 10^{7} \mathrm{~N} / \mathrm{m}^{2}(275000 \mathrm{psi})$; speed, $10000 \mathrm{rm}$; temperature $350 \mathrm{~K}\left(170^{\circ} \mathrm{F}\right)$; lubricant super-refined naphthenic mineral oil.

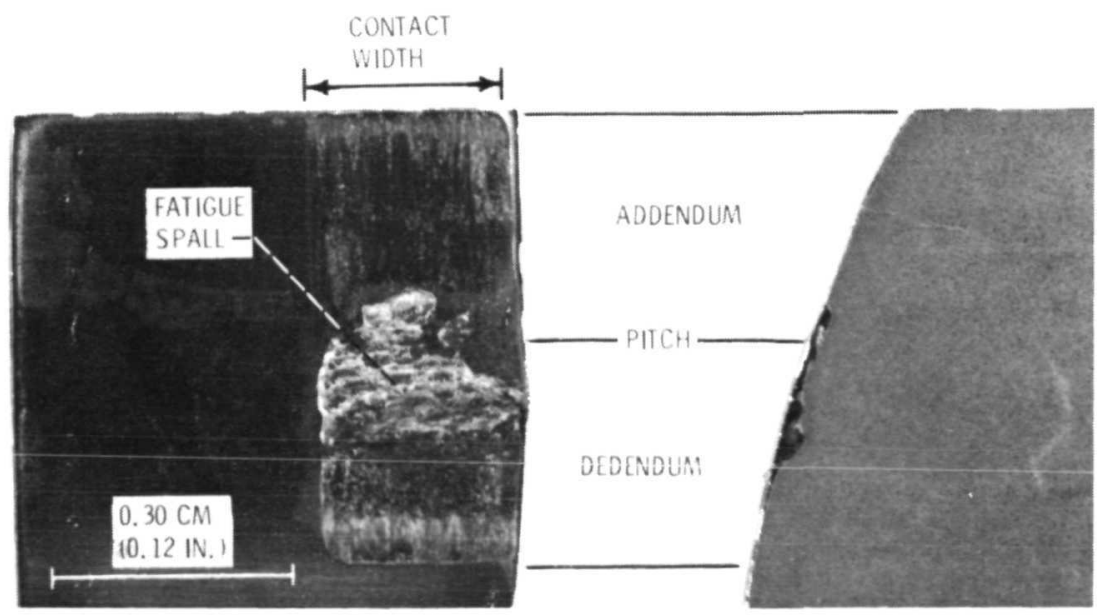

Figure 6. - Typical pitch-line fatigue spall on AISI M-50 steel gear. 


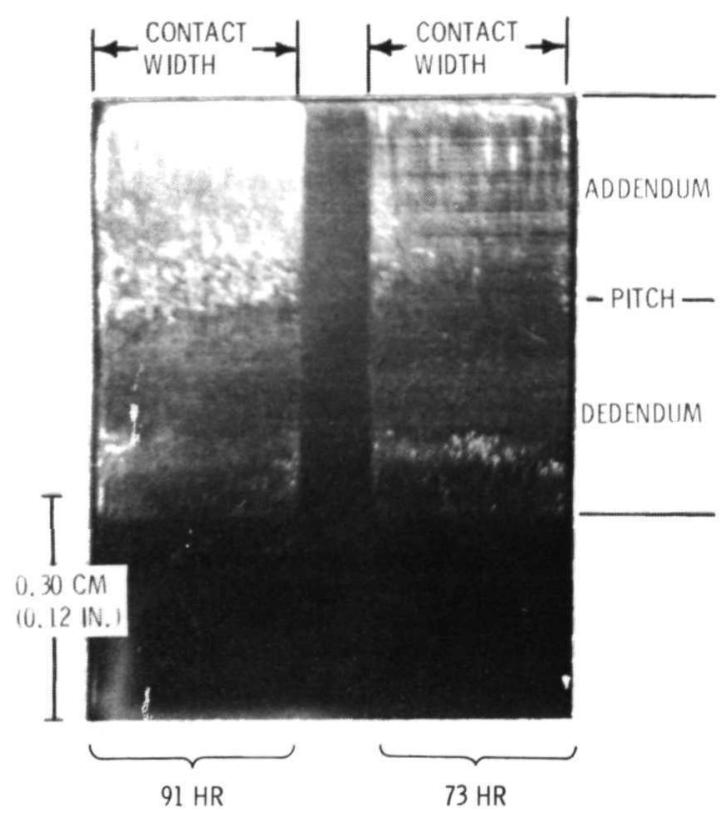

Figure 7. - Typical unfailed gear tooth, with contact surfaces that hed completed 91 hours and 73 hours.
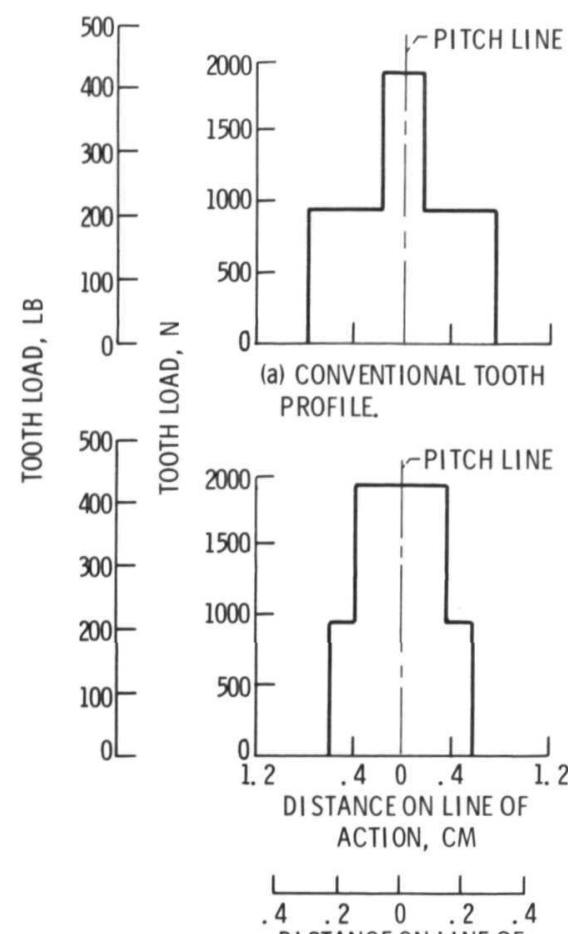

ACTION, CM

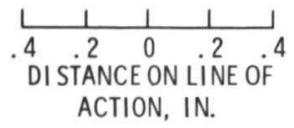

(b) $1.27 \times 10^{-3} \mathrm{CM}\left(5 \times 10^{-4}\right.$ IN. $)$ EXCESS TIP RELIEF.

Figure 8. - Load diagram for gear tooth with excess tip relief compared to load diagram for conventional tooth profile.

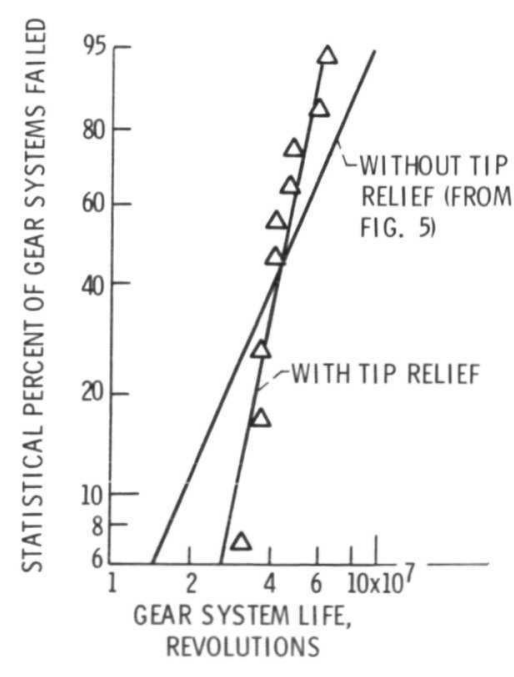

Figure 9. - Pitting fatigue lives of spur gear systems made of CVM super nitralloy (5Ni-2AI) with and without tip relief. Maximum Hertz stress at pitch line, $190 \times 10^{7}$ $\mathrm{N} / \mathrm{m}^{2}$ (275 000 psi); speed, 10000 $\mathrm{rpm}$; temperature, $350 \mathrm{~K}\left(170^{\circ} \mathrm{F}\right)$; lubricant, super-refined naphthenic mineral oil.

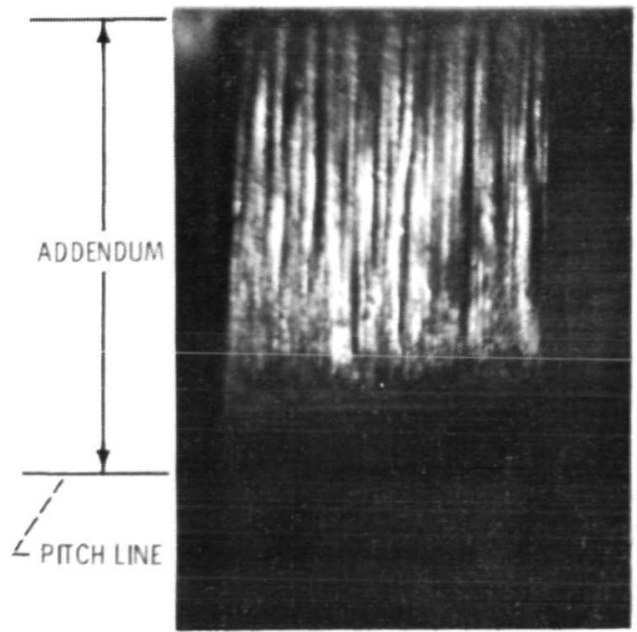

Figure 10. - Scoring failure on Super Nitralloy gear tooth with tip relief. 


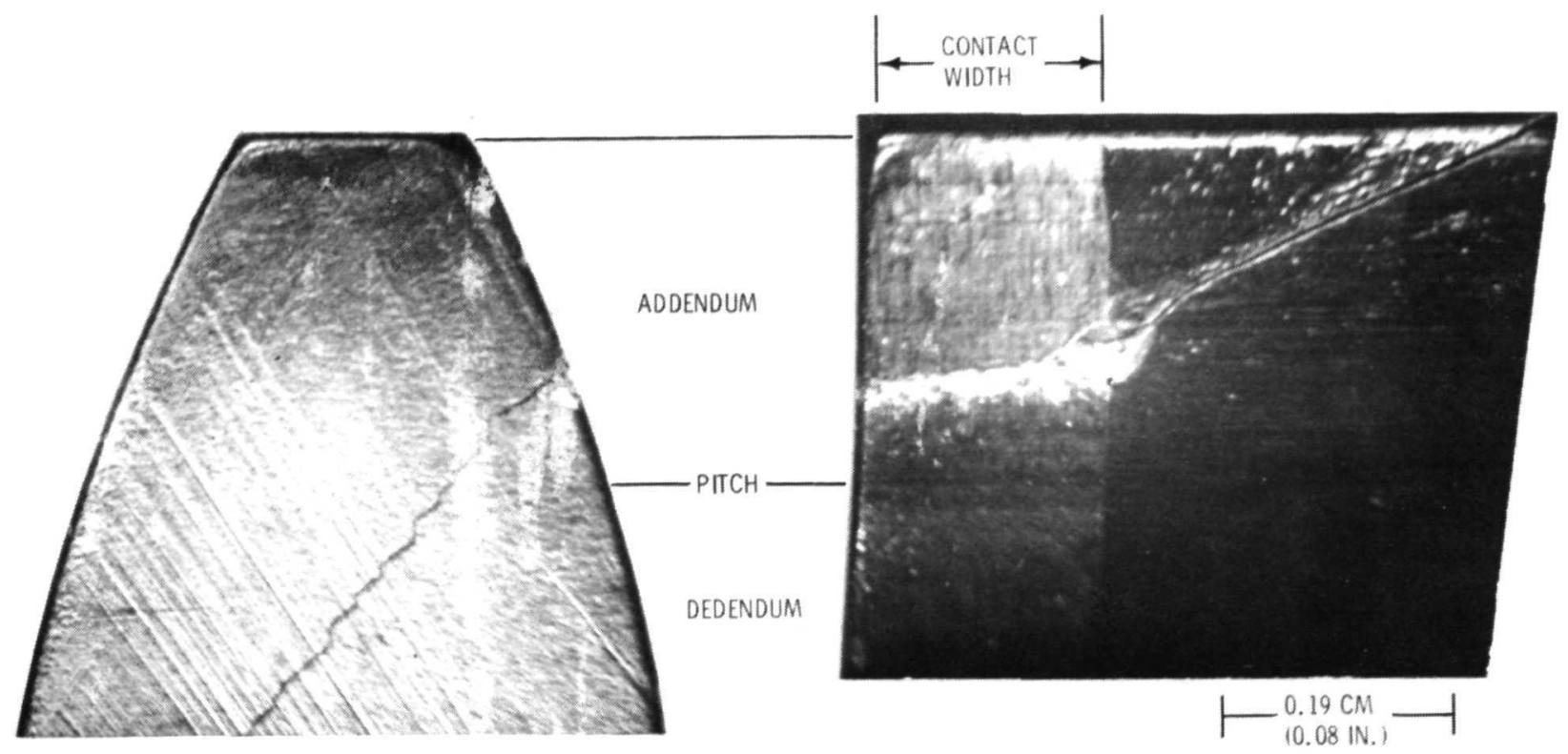

(a) TOOTH FRACTURE ORIGIN IN ADDENDUM.

Figure 11. - Fatigue fracture of AISI M-50 gear teeth with tip relief.

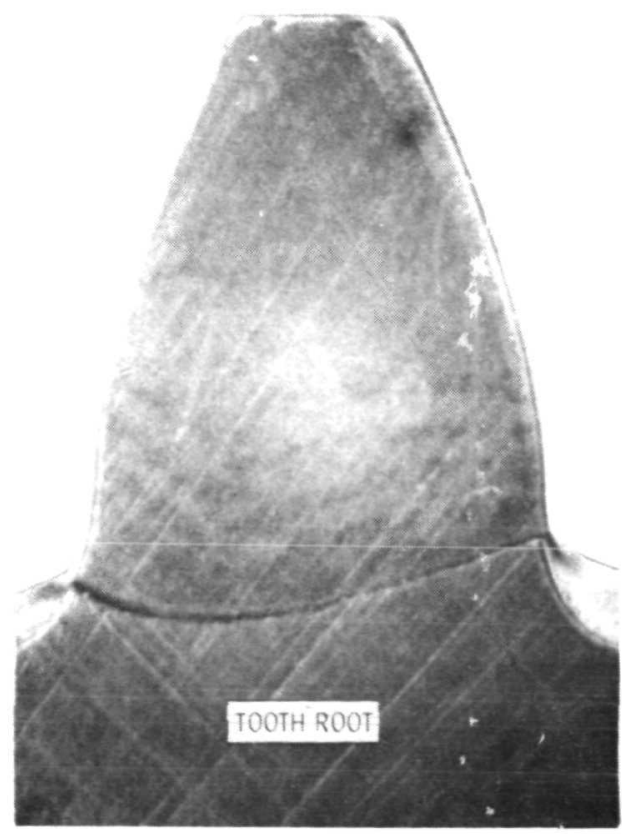

(b) TOOTH FRACTURE ORIGIN IN ROOT.

Figure 11. - Concluded. 